\title{
HANDLING OF UNCERTAINTIES IN ATTRIBUTING THERMOSHOCK IN FIBROUS CONCRETE STRENGTH: A PROBABILISTIC APPROACH
}

\begin{abstract}
G. ELANGOVAN"1, V.M. RAJANANDHINI ${ }^{2}$
Hallmark professionalism in probabilistic analysis is to quantify the uncertainties involved in construction materials subject to intrinsic randomness in its physical and mechanical properties and is now gaining popularity in civil engineering arena. As well, knowledge of behaviour of materials is continuously evolving and its statistical descriptors are also changing when more and more data collected or even data updated and hence reliability analysis has to be carried out with the updated data as a continuous process. As per the committee report ACI 544.2R, it is found that there is no attempt made for probabilistic relation between cube compressive strength and cylinder compressive strength for fiber reinforced concrete. In consequence of this report, a robust relation between cube and cylinder of experimentally conducted compressive strength was established by Monte-Carlo simulation technique for different types of fibrous concrete like steel, alkali resistant glass and polyester fibrous concrete before and after thermoshock considering various uncertainties. Nevertheless simulated probabilistic modals, characteristic modals, optimized factor of safety and allowable designed cylinder compressive strength have been developed from the drawn probability of failure graph, which exhibits robust performance in realistic Civil Engineering materials and structures.
\end{abstract}

Keywords: Fibrous concrete, Normal distribution, Probability, Quality control, Reliability, Thermoshock.

\section{INTRODUCTION}

Most of the Countries follow cube specimen and some countries use cylinder specimen for finding compressive strength of concrete. Generally cylinder compressive strength is crookedly taken as

\footnotetext{
${ }^{1}$ HOD., Department of Civil Engineering, University College of Engineering, Thirukkuvalai, Nagapattinam - 610204 , TamilNadu, India, e-mail : kgeln@rediffmail.com

${ }^{2}$ Assistant Professor. University College of Engineering, Department of Civil Engineering, Thirukkuvalai,

Nagapattinam - 610 204, TamilNadu, India, e-mail: nandhini_manju@yahoo.co.in
} 
0.8 times the strength of cube compressive strength but experiments have shown that there is no unique relationship between cube and cylinder compressive strength. Similar situation is existing for fibrous concrete also. Nowadays strength of structural materials is required after fire extinguished with water leads to themroshock. Strength from cube or cylinder specimen is currently required for fibrous concrete with its different types to predict one from the other before and after thermoshock. A number of researchers have reported that experimental tests are carried out for the compressive strength of fibrous concrete either by using cube or cylinder specimen. Most of the researches depict that on increasing the volume of fibres, compressive strength is also increased up to the volume of 1 percent and beyond this volume of fibres improvement was not effective. Some studies report that effect of size and shape of concrete specimen affects the relation between cube and cylinder compressive strength. Also it was suggested by various researchers that there is loss in strength and also in other properties of concrete and steel at elevated temperature Elevated temperature has significant effect on compressive strength in the hot and cold states and there is $15 \%$ definite loss of compressive strength from its original strength at 150 degree Celsius[1-5]. It was also found that thermal cycles have adverse effect on the compressive strength of ordinary concrete.

The compressive strength of ordinary concrete for M20 and M30 decreased by about $13 \%$ at $50^{\circ} \mathrm{C}$ after 28 thermal cycles. The resistance to adverse effect of thermo cycles is more for fly ash concrete when compared to ordinary concrete. While referring earlier experimental studies and committee report ACI $544.2 \mathrm{R}$, it is found that experiments were carried out for compressive strength of fibrous concrete either in cube or cylinder specimen and there is no attempt made to relate cube compressive strength to cylinder compressive strength for fibre reinforced concrete. Moreover finding the robust relation between them is very difficult due to uncertainties involved in concrete as well as fibres properties or may be due to insufficient data [6-11]. In consequence of the report ACI and for handling uncertainties, Monte-Carlo simulation technique is applied for assessing the strength of fibrous concrete. By using this technique, a novelty endeavour by probabilistic analysis has been attempted for relation between cube and cylinder compressive strength by considering strength as random variable which depends on complex material properties of different types of fibrous concrete like steel, alkali resistant glass and polyester fibrous concrete before and after thermoshock. Nevertheless simulated probabilistic modals, characteristic modals, reliability based optimized safety factor and allowable designed cylinder compressive strength, have been developed and such models exhibit robust performances in realistic civil engineering structures. 


\section{EXPERIMENTAL WORKS}

The properties of ingredients are shown in table 1.The details of fibres used in this study are presented in table 2. Chemical admixture like organic based and naphthalene based Super plasticisers were used for taking care of workability of concrete while adding fibres and uniform dispersion of fibres. Details of basic ingredients required for reference mix and reproportioned mix by super plasticiser are presented in table 3 . In this attempt all the experiments have been conducted keeping concrete cube size as $150 \mathrm{~mm}$ and cylinder size as $150 \mathrm{~mm}$ X $300 \mathrm{~mm}$ (slenderness ratio height/Diameter ratio as 2). After 28 days normal curing, compressive strength of fibrous concrete in cube and cylinder specimen was found. To conduct thermo shock test, all the

Table 1. Properties of Ingredients

\begin{tabular}{|c|c|}
\hline ITEMS & PROPERTIES \\
\hline Specific gravity of cement & 3.10 \\
\hline Specific gravity of coarse aggregates & 2.65 \\
\hline Specific gravity of fine aggregates & 2.60 \\
\hline Grade of sand & zone II \\
\hline Water absorption of coarse aggregates & $1.1 \%$ \\
\hline Water absorption of fine aggregates & $2.51 \%$ \\
\hline
\end{tabular}

Table 2. Details of fibres used

\begin{tabular}{|c|c|c|c|}
\hline PROPERTIES & $\begin{array}{c}\text { CORRUGATED } \\
\text { STEEL FIBRE }\end{array}$ & AR GLASS FIBRE & POLYESTER FIBRE \\
\hline Specific gravity & 7.86 & 2.6 & 1.334 \\
\hline Number of Fibres/kg & 22,820 Nos & 212 Million & Millions \\
\hline cut length 'mm' & 36 & 12 & 12 \\
\hline Diameter 'mm' & 0.45 & 0.015 & 0.045 \\
\hline Aspect ratio & $80: 1$ & $857: 1$ & $267: 1$ \\
\hline
\end{tabular}

Table 3. Mix Details

\begin{tabular}{|c|l|c|l|}
\hline MIX & \multicolumn{1}{|c|}{ PROPORTIONS } & MIX & \multicolumn{1}{c|}{ PROPORTIONS } \\
\hline R & $1: 1.60: 2.90: 0.49$ & R & $1: 1.60: 2.90: 0.49$ \\
\hline OSP & $\begin{array}{l}1: 1.80: 3.50: 0.49+0.8 \% \text { SP (Organic } \\
\text { Based ) }\end{array}$ & NSP & $\begin{array}{l}1: 1.80: 3.50: 0.49+0.8 \% \text { SP } \\
\text { (Naphthalene Based) }\end{array}$ \\
\hline OS1 $\ldots$ OS5 & ASP $+(0.2 \%, 0.4 \%, 0.6 \%, 0.8 \%, 1 \%)$ SF & NS1 $\ldots$ NS5 & BSP $+(0.2 \%, 0.4 \%, 0.6 \%, 0.8 \%, 1 \%)$ SF \\
\hline OG1 $\ldots$ OG5 & ASP $+(0.2 \%, 0.4 \%, 0.6 \%, 0.8 \%, 1 \%)$ ARGF & NG1 $\ldots$ NG5 & BSP $++(0.2 \%, 0.4 \%, 0.6 \%, 0.8 \%, 1 \%)$ ARGF \\
\hline OP1 $\ldots$ OP5 & ASP $+(0.2 \%, 0.4 \%, 0.6 \%, 0.8 \%, 1 \%)$ PF & NP1 .NP5 & BSP $+(0.2 \%, 0.4 \%, 0.6 \%, 0.8 \%, 1 \%)$ PF \\
\hline
\end{tabular}

specimens after 28 days curing were placed inside the hot air oven and were heated to a temperature of 200 degree Celsius sustained for two hours. Then the specimens were taken out from oven with some precaution. All the heated specimen were immediately quenched in water and the cooling was 
done for about half an hour. The specimens were then tested under compression testing machine. All the experimental test results in a shortened form are presented in table 4.

Table 4. Ratio between Cube and Cylinder Compressive strength of fibrous concrete

\begin{tabular}{|c|c|c|c|c|c|}
\hline $\begin{array}{c}\text { NO of } \\
\text { MIXES }\end{array}$ & MIX & $\begin{array}{c}\text { CYLINDER } \\
\text { COMP } \\
\text { STRENGTH } \\
\text { by EXP } \\
\text { CY } \\
\text { MPa }\end{array}$ & $\begin{array}{c}\text { CUBE } \\
\text { COMP } \\
\text { STRENGTH } \\
\text { by EXP } \\
\text { CX MPa }\end{array}$ & RATIO= & $\begin{array}{c}\text { PREDICTED } \\
\text { CYLINDER } \\
\text { COMP } \\
\text { STRENGTH } \\
\text { by } \\
\text { MODEL-3.7 }\end{array}$ \\
\hline 1 & R & 19.62 & 27.11 & 0.723 & 18.43 \\
\hline 2 & OSP & 24.32 & 38.16 & 0.637 & 25.95 \\
\hline 3 & OS1 & 24.89 & 38.26 & 0.651 & 26.02 \\
\hline 4 & OS2 & 24.95 & 38.34 & 0.651 & 26.07 \\
\hline 5 & OS3 & 25.65 & 39.55 & 0.649 & 26.89 \\
\hline 9 & OG2 & 18.71 & 28.74 & 0.651 & 19.54 \\
\hline 10 & OG3 & 18.73 & 28.77 & 0.651 & 19.56 \\
\hline 11 & OG4 & 21.20 & 32.30 & 0.656 & 21.96 \\
\hline 16 & OP4 & 21.41 & 32.88 & 0.651 & 22.36 \\
\hline 17 & OP5 & 22.45 & 34.51 & 0.651 & 23.47 \\
\hline 94 & T-NG5 & 31.24 & 46.43 & 0.673 & 31.63 \\
\hline 95 & T-NP1 & 25.65 & 38.16 & 0.672 & 26.00 \\
\hline 96 & T-NP2 & 25.75 & 38.48 & 0.669 & 26.22 \\
\hline 97 & T-NP3 & 28.05 & 38.04 & 0.737 & 25.92 \\
\hline 98 & T-NP4 & 28.52 & 38.21 & 0.746 & 26.04 \\
\hline 99 & T-NP5 & 27.33 & 38.55 & 0.709 & 26.27 \\
\hline & & & & & \\
\hline
\end{tabular}

\section{Probability ANALYSIS BY MONTE CARLO SIMULATION}

In this experimental work, compressive strength of fibrous concrete is treated as a random variable in which there are several uncertainties which contributes total variation in strength due to variations in the quality of concrete ingredients, fibres properties, weighing, mixing, curing and testing procedures. As well, knowledge of behaviour of materials is continuously evolving and its statistical descriptors are also changing when more and more data collected or data updated. Nevertheless getting all the field data for different ingredients of fibrous concrete is quite impossible and expensive equally. To resort such situation, simulation techniques are the only powerful tool for analyzing response of randomly driven system which is typically governed by different equation. This is driven by ensemble of inputs which are compatible with prescribed probabilistic model and characterizing the model by suitable distribution like normal or lognormal distribution. Later simulating ensemble of random numbers which are compatible with given power density function of the system, response quantities of interest is processed statistically to estimate 
parameters or descriptors like mean, variance, skewness and kurtosis by the method of moment. Consequently probabilistic analysis was made in the following two phases for finding relation $\mathrm{R}^{*}$ between cube and cylinder compressive strength of different fibrous concrete.

In phase-I, by referring table 4, reliability analysis was carried out for analysing experimentally conducted cube and cylinder compressive strength ( $\mathrm{Cx}$ and $\mathrm{CY}$ ) of different fibrous concrete by considering various material properties involved in it for establishing the respective probabilistic strength along with its coefficient of variation and probability density function for its type of distribution. Statistical parameters are presented in table $5 \& 6$. While looking at the value of the coefficient of variation $\mathrm{COV}$, all the values of $\mathrm{COV}$ are found within the allowable value $15 \%$ and it conforms that all the test results are in good quality control.

Table. 5. Statistical Properties of Random variables of fibrous concrete cube

\begin{tabular}{|c|c|c|c|c|}
\hline \multirow{2}{*}{ METHOD of TEST } & TYPE of FIBRE & $\begin{array}{c}\text { Log } \\
(\text { mean }) \sim\end{array}$ & $\begin{array}{c}\text { Cov } \\
\%\end{array}$ & $\begin{array}{c}\text { TYPE of } \\
\text { DISTRIBUTION }\end{array}$ \\
\hline \multirow{3}{*}{ Before Thermo shock } & Steel Fibre & 3.770 & 8.480 & LN \\
\cline { 2 - 5 } & AR Glass Fibre & 3.770 & 9.200 & LN \\
\cline { 2 - 5 } & Polyester Fibre & 3.730 & 5.150 & LN \\
\hline \multirow{3}{*}{ After Thermo shock } & Steel Fibre & 3.688 & 9.150 & LN \\
\cline { 2 - 5 } & AR glass Fibre & 3.695 & 10.500 & LN \\
\cline { 2 - 5 } & Polyester Fibre & 3.611 & 3.640 & LN \\
\hline
\end{tabular}

Table. 6. Statistical Properties of Random variables of fibrous concrete cylinder

\begin{tabular}{|c|c|c|c|c|}
\hline METHOD of TEST & TYPE of FIBRE & $\begin{array}{c}\log \\
(\text { mean }) \sim\end{array}$ & $\underset{\%}{\mathrm{COV}}$ & $\begin{array}{c}\text { TYPE of } \\
\text { DISTRIBUTION }\end{array}$ \\
\hline \multirow{3}{*}{ Before Thermo shock } & Steel Fibre & 3.432 & 10.800 & $\mathrm{LN}$ \\
\hline & AR Glass Fibre & 3.470 & 12.300 & LN \\
\hline & Polyester Fibre & 3.397 & 8.200 & $\mathrm{LN}$ \\
\hline \multirow{3}{*}{ After Thermo shock } & Steel Fibre & 3.237 & 12.200 & $\mathrm{LN}$ \\
\hline & AR Glass Fibre & 3.275 & 13.300 & $\mathrm{LN}$ \\
\hline & Polyester Fibre & 3.205 & 9.300 & $\mathrm{LN}$ \\
\hline
\end{tabular}

In phase-II, using the data from phase-I Monte-Carlo simulation technique was used to simulate the complete random behaviour of relation between cube and cylinder compressive strength of different types of individual fibrous concrete before and after thermoshock $R_{i=103}^{*}, R_{i=4 t o 6}^{*}$ espectively as shown in table 7 and probabilistic models are obtained for different fibrous concrete. 
This technique offers solutions which are compatible with experimental data but simulation processes requires a very large number of random numbers for analyzing uncertainty propagation. From simulation, probability distribution, cumulative distribution of $\mathrm{R}^{*}$ for various types of fibrous concrete and lognormal probability paper plot were obtained. A computer programme was developed to handle sampling and distribution of random variables, and its simulation is explained briefly here.

1. Generating ten thousand random cube compressive strength with defined coefficient of variation individually for steel, AR glass and polyester fibrous concrete before and after thermoshock from the table 5 .

2. Generating ten thousand random cylinder compressive strength with defined coefficient of variation individually for each fibrous concrete as step 1 from the table 6 .

3. Normalization between 0 to 1 was made for relation $R^{*}$ between cube and cylinder compressing strength of fibrous concrete. Normalized ratio $\mathrm{R}^{*}$ was used for computation of probabilistic models for each fibrous concrete before and after thermoshock.

4. Determination of statistical properties like mean, COV, skewness and kurtosis for different types of fibrous concrete before and after thermoshock of the relation $\mathrm{R}^{*}$ generated.

5. In the present study, Relation $\mathrm{R}^{*}$ is considered satisfactory if mean, $\mathrm{COV}$ and other statistical parameters are converged after $\mathrm{N}$ number of cycles by repeating the steps 1 to 4 to get uniform reliability index and probability of failures.

Reliability Index $\beta=\frac{\mu}{\sigma}$ where $\mu, \sigma$ are mean and standard deviation.

Probability of failure $\mathrm{P}_{\mathrm{f}}=\Phi(-\beta)=1.0-\Phi(\beta)$

where $\Phi$ is Cumulative distributed function (CDF).

It means while $\beta$ is large, the probability of failure will be very small.

Factor of safety is calculated by ratio between relation obtained from simulation and allowable ratio, $\delta=\frac{R^{*}}{R_{a}^{x}}$, and allowable ratio $\mathrm{R}_{\mathrm{a}}{ }^{*}=\mathrm{R}^{*}(1+\mathrm{u} \delta \mathrm{x})$ where $\mathrm{u}$ is standard normal variate and $\delta \mathrm{x}$ is coefficient of variation COV. 


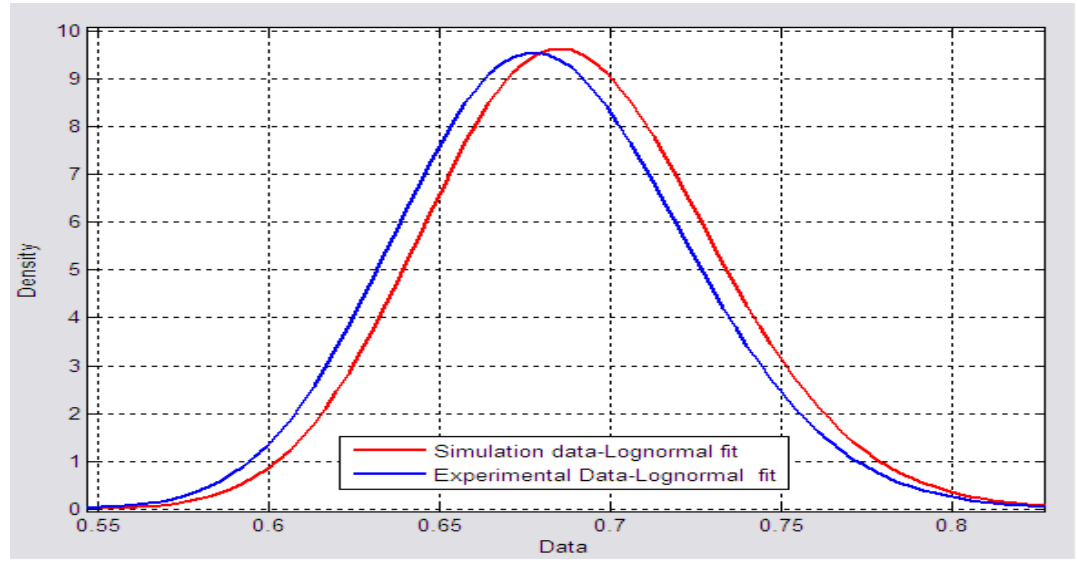

Fig. 1. Frequency distribution of $\mathrm{R}_{7}{ }^{*}$ of Experimental and Simulated data

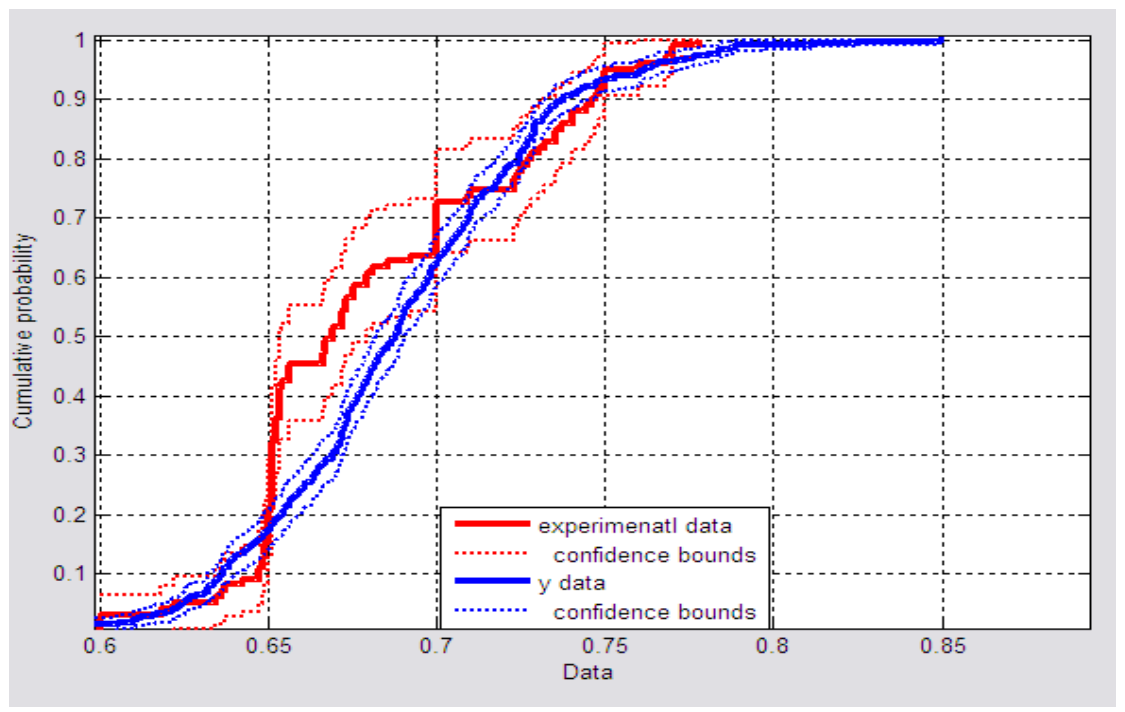

Fig. 2. Cumulative distribution of $\mathrm{R}_{7}{ }^{*}$ for experimental and Simulated data 


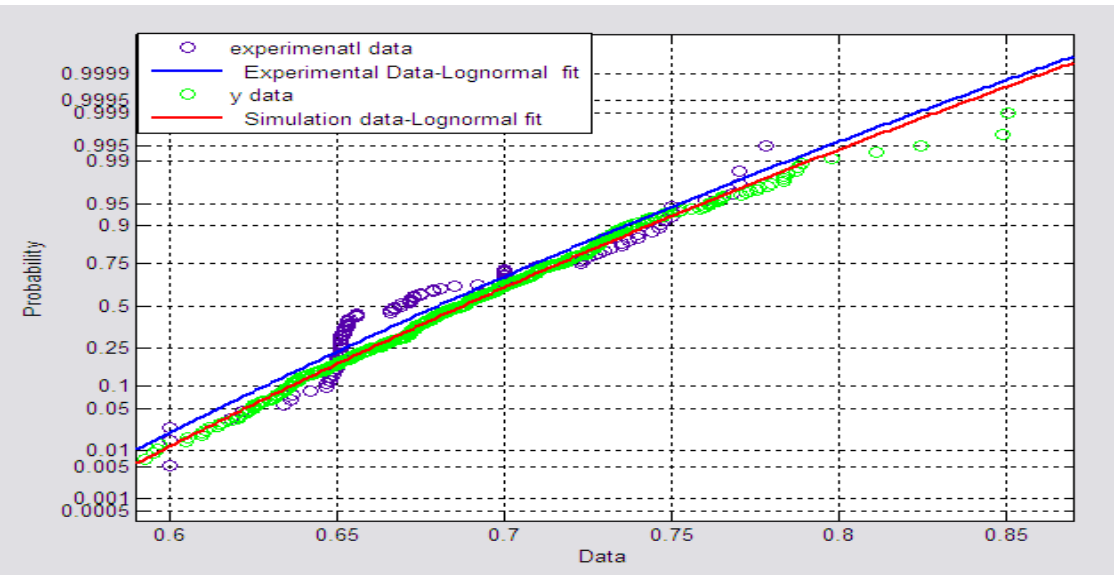

Fig. 3. Log Normal Probability Paper Plot for $\mathrm{R}_{7}{ }^{*}$

All the probabilistic results are presented in table 7. Mean value obtained from experimental values are found to be very close to the results obtained from simulation technique. The coefficient of variation of different fibrous concrete are found as higher values than the values obtained before thermoshock. It was expected that coefficient of variation would fall out of the allowable value $15 \%$ after thermoshock. But invariably all the coefficients of variations of different types of fibres are found to be within the allowable value of $15 \%$.

Heretofore probabilistic analysis was made individually for different types of fibrous concrete which consists of different densities. When sufficient data is not available for particular type of fiber in such situation a generalized probabilistic modal is to be arrived irrespective of type of fibers used. In this analysis, 99 ratios were considered from the mixes R to T-NP5 as in table 4. From the simulation, generalised relation for fibrous concrete $R_{7}^{*}$ was obtained. In general all the fibrous concrete have reliability more than 3.9 and a very low probability of failure which indicates all ratios $R_{i=3.1 t 03.6}^{*}$ as well $R_{3.8}^{*}$ can be considered to be more reliable from safety point of view.

\section{Novel Simulated Probabilistic Models before thermoshock:}

(3.1) For Steel fibre $\quad C Y=0.7207 \mathrm{X}$ Cube compressive Strength $(\mathrm{Cx})$

(3.2) For AR glass fibre $C Y=0.7213 \times$ Cube compressive Strength $(\mathrm{Cx})$

(3.3) For Polyester fibre $C Y=0.7199 \mathrm{X}$ Cube compressive Strength $(\mathrm{Cx})$ 


\section{Novel Simulated Probabilistic Models after thermoshock:}

For Steel fibre $\quad C Y=0.6456 \mathrm{X}$ Cube compressive Strength $(\mathrm{Cx})$

For AR glass fibre $C Y=0.6687 \mathrm{X}$ Cube compressive Strength $(\mathrm{Cx})$

For Polyester fibre $C Y=0.6704 \mathrm{X}$ Cube compressive Strength $(\mathrm{Cx})$

Novel Simulated Probabilistic generalized Model for any type of fiber:

$C Y=0.69 \times$ Cube compressive Strength $(\mathrm{Cx})$

Novel Simulated Probabilistic generalized characteristic Model for any type of fiber: $C Y=0.63 \mathrm{X}$ Cube compressive Strength $(\mathrm{Cx})$

\section{INFERRENCES FROM THE PROBABILITY FAILURE GRAPH}

'Probability failure graph' is drawn between factor of safety and probability failure. Failure graphs are shown in figures 4, 5 and 6 in both linear and logarithmic scales. It is seen that highly non-linear variation of failure probabilities were obtained. While decreasing the failure probability, factor of safety increases vice-versa. In the figure 4, variations for steel and AR glass fibrous concrete coincide while polyester fibrous concrete deviated from the above two. From the figure 4, reducing safety factor from 2 to 1.85 does not affect failure probability critically. But reducing the safety factor from 1.85 to 1.45 causes serious effect on probability of failure and this range is considered as dangerous zone. It is also seen that on further increasing the safety factor from 2 to 3 will decrease the allowable ratio $\mathbf{R}_{\mathbf{A}}{ }^{*}$ which in turn decrease the design cylinder strength leads larger section and increase the cost of the section with no important increase in reliability. Similarly in polyester fibrous concrete, there is no change in failure probability on reducing factor of safety 2 to 1.4. It is disastrous while further reducing safety factor. Hence from the figure 4, optimized factor of safety is to be evaluated for the best designing of structures. It is inferred that optimized safety factor for steel, AR glass and polyester fibrous concrete is found to be 1.74, 1.72 and 1.56 before thermoshock respectively. Figure 5 shows the non-linear variation between safety factor and failure of probabilities after thermoshock and optimized safety factor for steel, AR glass and polyester fibrous concrete is 1.9, 2.12 and 1.45 after thermoshock respectively. Similarly figure 6 shows the non-linear variation between safety factor and failure of probability for any type of fibrous concrete. Safety factor for fibrous concrete is 1.66. It shows how probability analysis guides for selection of factor of safety. 
Table 7. Probabilistic Values of Ratio between cube and cylinder fibrous concretes

\begin{tabular}{|c|c|c|c|c|c|c|c|c|c|c|c|c|c|}
\hline \multirow{3}{*}{$\begin{array}{l}\text { Meth } \\
\text { od } \\
\text { of } \\
\text { Test }\end{array}$} & \multirow{3}{*}{$\begin{array}{l}\text { Type } \\
\text { of } \\
\text { Fibre }\end{array}$} & \multirow{3}{*}{ 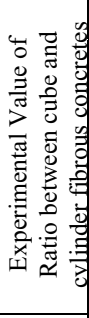 } & \multicolumn{11}{|c|}{ Probabilistic Values of Ratio between cube and cylinder fibrous concretes } \\
\hline & & & \multirow{2}{*}{ 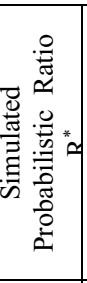 } & \multirow[b]{2}{*}{$\begin{array}{l}\mathrm{CO} \\
\mathrm{V} \\
\%\end{array}$} & \multirow{2}{*}{ 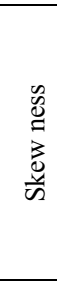 } & \multirow[b]{2}{*}{ 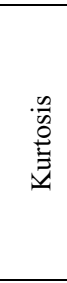 } & \multicolumn{2}{|c|}{$\begin{array}{l}\text { Kolmogoro } \\
\text { v Smirnov } \\
\text { Test (KS) }\end{array}$} & \multicolumn{2}{|c|}{$\begin{array}{c}\text { Chi Squared } \\
\text { Test }\end{array}$} & \multirow{2}{*}{ 点葛 } & \multirow[b]{2}{*}{$\begin{array}{l}\text { Reliab } \\
\text { ility } \\
\text { Index }\end{array}$} & \multirow[b]{2}{*}{$\begin{array}{c}\text { Probabil } \\
\text { ity of } \\
\text { Failure }\end{array}$} \\
\hline & & & & & & & $\begin{array}{c}\mathrm{K} \sim \mathrm{S} \\
\text { Test } \\
\text { Value } \\
- \\
\text { Data }\end{array}$ & $\begin{array}{c}\mathrm{K} \sim \mathrm{S} \\
\text { Test } \\
\text { allo } \\
\text { wable } \\
\text { Value } \\
*\end{array}$ & $\begin{array}{c}\text { Chi- } \\
\text { squa } \\
\text { red } \\
\text { Value } \\
- \\
\text { Data }\end{array}$ & $\begin{array}{c}\text { Chi- } \\
\text { squared } \\
\text { allowa } \\
\text { ble } \\
\text { Value* }\end{array}$ & & & \\
\hline \multirow{3}{*}{$\begin{array}{l}\text { Befor } \\
\text { Ther } \\
\text { mo } \\
\text { shock } \\
R_{3 . i=1 t o 3}^{*}\end{array}$} & $\begin{array}{l}\text { Steel } \\
\text { Fibre }\end{array}$ & 0.710 & 0.720 & 13.80 & 0.44 & 3.57 & 0.009 & \multirow{7}{*}{$\frac{9}{0}$} & 15.8 & \multirow{7}{*}{21.026} & $\mathrm{LN}$ & 5.76 & 4.56E-09 \\
\hline & $\begin{array}{c}\text { AR } \\
\text { Glass } \\
\text { Fibre }\end{array}$ & 0.737 & 0.721 & 13.6 & 0.37 & 3.19 & 0.005 & & 8.28 & & $\mathrm{LN}$ & 4.88 & $5.34 \mathrm{E}-07$ \\
\hline & $\begin{array}{l}\text { Poly } \\
\text { ester } \\
\text { Fibre } \\
\end{array}$ & 0.717 & 0.719 & 9.70 & 0.33 & 3.10 & 0.010 & & 8.34 & & $\mathrm{LN}$ & 7.44 & $4.75 \mathrm{E}-14$ \\
\hline \multirow{3}{*}{$\begin{array}{c}\text { After } \\
\text { Ther } \\
\text { mo } \\
\text { shock } \\
R_{3 i=4 t o 6}^{*}\end{array}$} & $\begin{array}{l}\text { Steel } \\
\text { Fibre }\end{array}$ & 0.637 & 0.645 & 15.2 & 0.44 & 3.33 & 0.01 & & 20.3 & & $\mathrm{LN}$ & 4.22 & $1.17 \mathrm{E}-05$ \\
\hline & $\begin{array}{c}\text { AR } \\
\text { Glass } \\
\text { Fibre }\end{array}$ & 0.658 & 0.668 & 17.1 & 0.46 & 3.23 & 0.009 & & 16.3 & & $\mathrm{LN}$ & 3.93 & $4.22 \mathrm{E}-05$ \\
\hline & $\begin{array}{l}\text { Poly } \\
\text { ester } \\
\text { Fibre } \\
\end{array}$ & 0.668 & 0.670 & 10.0 & 0.29 & 3.16 & 0.007 & & 5.87 & & $\mathrm{LN}$ & 6.69 & $1.1 \mathrm{E}-11$ \\
\hline$R_{3.7}^{*}$ & $\begin{array}{c}\text { Any } \\
\text { Fibre } \\
\text { (Gen } \\
\text { eral } \\
\text { case) }\end{array}$ & 0.690 & 0.690 & 12.9 & 0.39 & 3.39 & 0.008 & & 7.56 & & $\mathrm{LN}$ & 5.32 & $1.67 \mathrm{E}-08$ \\
\hline
\end{tabular}

\section{DISCUSSION OF THE TEST RESULTS}

Average strength of specimens of all the test results are shown table 4. The individual variation of fibrous concrete strength was found as within the range of \pm 15 percent of the average. The mixes OSP and NSP were carried out to find out improvement in strength of fibrous concrete over OSP, NSP and reference mix. From the results of extensive experimental works conducted before and after thermoshock, it was observed that cube or cylinder compressive strength of concrete with steel and alkali resistant glass fibres have higher strength than polyester fibres. This may be due to the fact specific gravity of these two fibres are higher than concrete. Based on the general observation 
Table 8. Probabilistic, Characteristic and Allowable ratio for evaluating allowable designed Cylinder Compressive Strength

\begin{tabular}{|c|c|c|c|c|c|}
\hline $\begin{array}{c}\text { Method } \\
\text { of } \\
\text { Test }\end{array}$ & $\begin{array}{l}\text { Type } \\
\text { of } \\
\text { Fibre }\end{array}$ & $\begin{array}{c}\text { Simulated } \\
\text { probabilistic } \\
\text { Ratio } \mathrm{R}^{*}{ }_{\mathrm{i}}= \\
\mathrm{CY} / \mathrm{C}_{\mathrm{X}}\end{array}$ & $\begin{array}{c}\text { Characteristic } \\
\text { Ratio }= \\
\mathrm{CY} / \mathrm{C}_{\mathrm{X}}\end{array}$ & $\begin{array}{c}\text { Factor of Safety } \\
\text { FOS }\end{array}$ & $\begin{array}{l}\text { Allowable designed } \\
\text { Cylinder comp } \\
\text { Strength } \\
\mathrm{N} / \mathrm{mm}^{2} \\
\mathrm{R}_{\mathrm{A}}{ }^{*}=\mathrm{R}^{*}{ }_{3 . \mathrm{i}} / \text { Fos }\end{array}$ \\
\hline \multirow{3}{*}{$\begin{array}{l}\text { Before } \\
\text { Thermo } \\
\text { shock } \\
R_{3 . i=1 t o 3}^{*}\end{array}$} & Steel Fibre & 0.7200 & 0.6708 & 1.74 & 0.4071 \\
\hline & AR Glass Fibre & 0.7213 & 0.6873 & 1.72 & 0.4275 \\
\hline & Polyester Fibre & 0.7190 & 0.6647 & 1.56 & 0.4585 \\
\hline \multirow{3}{*}{$\begin{array}{l}\text { After } \\
\text { Thermo } \\
\text { shock } \\
R_{3 i=4 t o 6}^{*}\end{array}$} & Steel Fibre & 0.6456 & 0.5985 & 1.90 & 0.3381 \\
\hline & AR Glass Fibre & 0.6687 & 0.6052 & 2.12 & 0.3102 \\
\hline & Polyester Fibre & 0.6704 & 0.5834 & 1.45 & 0.4615 \\
\hline$R_{3.7}^{*}$ & $\begin{array}{c}\text { Any Fibre } \\
\text { (General case) }\end{array}$ & 0.690 & 0.6333 & 1.66 & 0.4149 \\
\hline
\end{tabular}

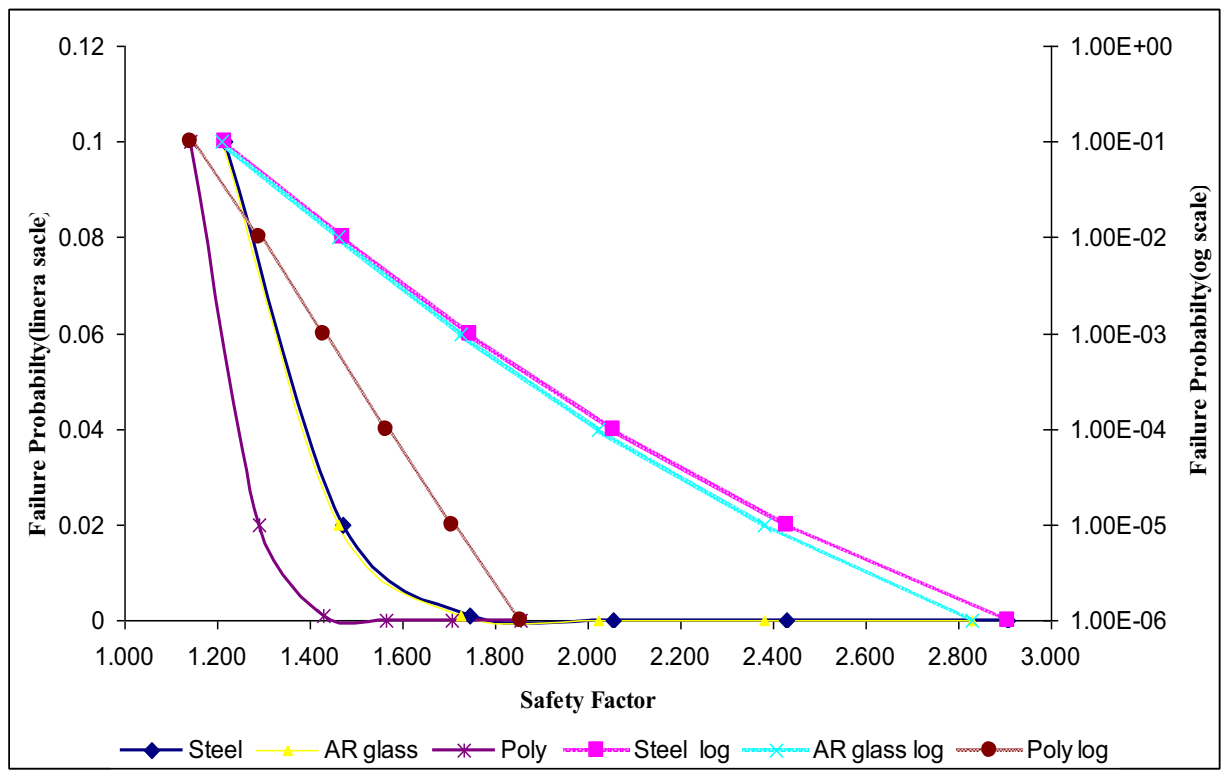

Fig. 4. Safety Factor vs Failure probability of fibrous concrete before thermoshock 


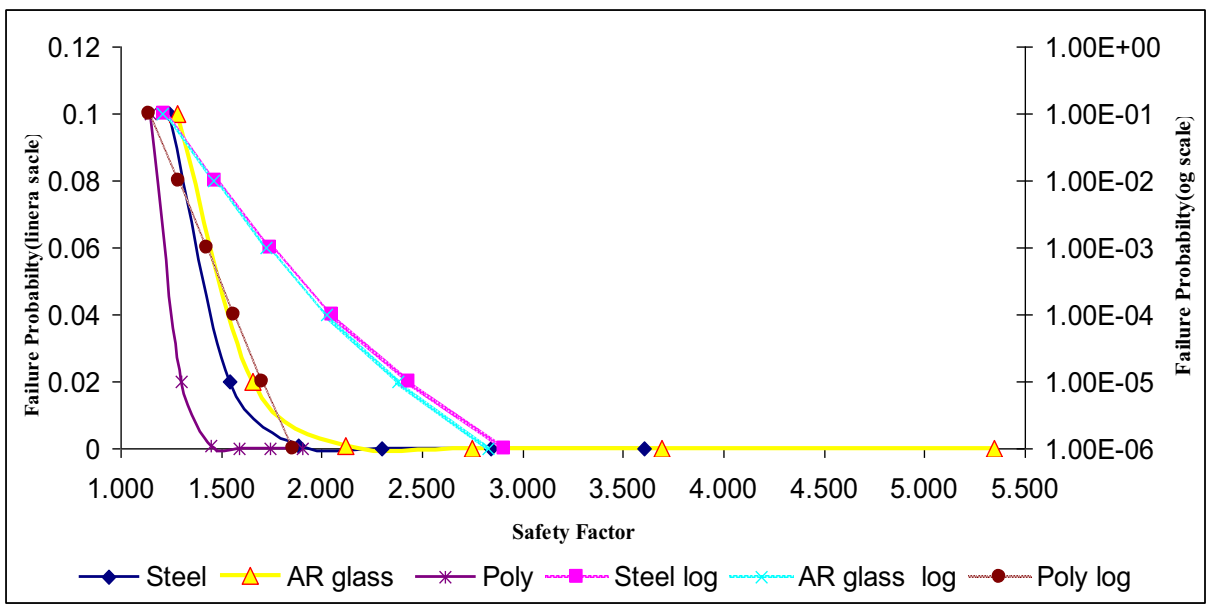

Fig. 5. Safety Factor vs Failure Probability of fibrous concrete after thermo shock

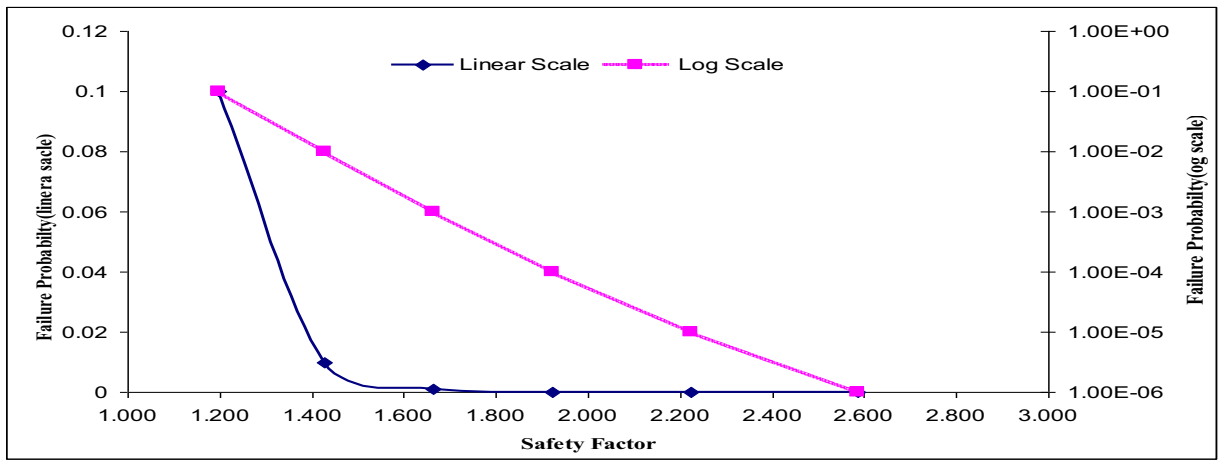

Fig. 6. Safety Factor vs Failure Probability of fibrous concrete before and after thermoshock

cube and cylinder compressive strength of fibrous concrete increased with the increase of fiber content from $0.2 \%$ to $1.0 \%$. It was also found that experimental results for cylinder compressive strength was lower than cube compressive strength as in table 4. It was expected that the specimens would lose its mass due to dehydration during thermoshock and consequently the unit weight would therefore decrease. But the unit weight of the different fibrous concretes were not affected by the thermal shock. There are some difference of opinion as regards the increase of compressive strength of concrete at the temperature ranges between 200 to 400 degree Celsius and added that no such improvement in strength of concrete on heating. While observing the experimental results as in table 4, it was found that almost compressive strength of concrete with cube and cylinder 
specimen decreased to nearly 10 percent to 15 percent of unheated specimen at each mixes under thermoshock test at 200 degree Celsius. It was found that mixes with AR Glass fibre under naphthalene based superplasticiser found strength after thermoshock is 0.97 times unheated specimen which concludes concrete mix AR Glass fibre is not much affected by thermoshock.

\section{VALIDATION}

It is quite indispensable to validate all types of modals developed here. From table 9, it has been found that simulated probabilistic Strength almost closely matches with earlier reported results.

Table.9. Comparative Analysis of probabilistic strength, characteristic strength and designed strength with reported Experimental strength

\begin{tabular}{|c|c|c|c|c|c|c|c|c|}
\hline \multirow{2}{*}{ Sl. No } & \multicolumn{3}{|c|}{$\begin{array}{c}\text { Reported } \\
\text { Experimental Strength } \\
\mathrm{N} / \mathrm{mm}^{2}\end{array}$} & \multicolumn{2}{|c|}{$\begin{array}{c}\text { Simulated } \\
\text { Probabilistic } \\
\text { Strength } \mathrm{N} / \mathrm{mm}^{2}\end{array}$} & \multirow{2}{*}{$\begin{array}{c}\text { Characteristic } \\
\text { Strength } \\
\mathrm{N} / \mathrm{mm}^{2} \\
\text { Cylinder } \\
\text { compressive } \\
\text { strength } \\
\text { by model-3.8 }\end{array}$} & \multirow{2}{*}{$\begin{array}{c}\text { Allowable } \\
\text { designed } \\
\text { Cylinder } \\
\text { comp } \\
\text { Strength } \\
\text { N/mm } \mathrm{mm}^{2} \\
\mathrm{R}_{\mathrm{a}}=\mathrm{R}^{*} / \text { Fos }\end{array}$} & \multirow{2}{*}{$\begin{array}{c}\text { Allowable } \\
\text { designed } \\
\text { Cylinder } \\
\text { comp } \\
\text { Strength } \\
\mathrm{N} / \mathrm{mm}^{2} \\
=0.67^{*} \\
\text { characteristic } \\
\text { strength }\end{array}$} \\
\hline & 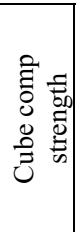 & 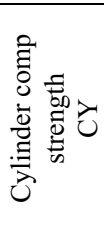 & $\begin{array}{l}\text { Ratio } \\
= \\
\mathrm{CY} / \\
\mathrm{C}_{\mathrm{X}}\end{array}$ & $\begin{array}{l}\text { Cylinder } \\
\text { compres } \\
\text { sive } \\
\text { strength } \\
\text { by } \\
\text { model- } \\
3.1\end{array}$ & $\begin{array}{l}\text { Cylinder } \\
\text { compress } \\
\text { ive } \\
\text { strength } \\
\text { by } \\
\text { model- } \\
3.7\end{array}$ & & & \\
\hline $\begin{array}{l}\text { Yaghoub } \\
\text { Mohamma } \\
\text { di et al } \\
{[2008]}\end{array}$ & 69.8 & 51.17 & 0.732 & 50.32 & 48.19 & 44.20 & 28.97 & 29.61 \\
\hline \multirow{2}{*}{$\begin{array}{l}\text { Ganesan et } \\
\text { al [2006] }\end{array}$} & 66.4 & 47.92 & 0.720 & 47.90 & 45.86 & 42.10 & 27.57 & 28.20 \\
\hline & 76.3 & 51.35 & 0.672 & 55.05 & 52.71 & 48.35 & 31.69 & 32.39 \\
\hline $\begin{array}{l}\text { NP5 7days } \\
\text { curing }\end{array}$ & 39.4 & 25.64 & 0.65 & 28.40 & 27.25 & 26.22 & 18.08 & 17.60 \\
\hline $\begin{array}{l}\text { NP5 } \\
\text { 28days } \\
\text { curing }\end{array}$ & 45.0 & 32.82 & 0.728 & 32.46 & 31.15 & 28.55 & 20.67 & 19.12 \\
\hline
\end{tabular}

\section{CONCLUSIONS}

In consequence of this report, a novelty endeavour by probabilistic analysis has been made by Monte-Carlo reliability analysis as an attempt for analyzing robust relation between cube and cylinder compressive strength of different types of fibrous concrete and some major conclusions were drawn from this research. 
I. Incredibly before and after thermoshock, cube and cylinder compressive strength of fibrous concrete was not getting affected and found to be increased invariably with the increase of volume of fibres.

II. Developed probabilistic models for relation between cube and cylinder compressive strength of different types of fibrous concrete like steel, alkali resistant glass and polyester fibrous concrete before and after thermoshock will be useful for obtaining the cylinder compressive strength of fibrous concrete.

III. Nevertheless characteristic models for relation are also developed for predicting the characteristic cylinder compressive strength from cube compressive strength of fibrous concrete. It will be ideally useful for design of reinforced concrete structures also optimized factor of safety and allowable designed cylinder compressive strength was also developed and such models exhibit robust performance in realistic civil engineering structures.

\section{REFERENCES}

1. N.S. Arabi Al Qadi,, Sleiman M. Alzaidyeen, Effect of fibre content and specimen shape on residual strength of polypropylene fibre self compacting concrete exposed to elevated temperatures, Journal of King Saud University Engineering Sciences, Vol 26, No. 1, pp. 33-39, 2014.

2. Patrick Oguguo Nwankwo, Emmanuelachuenu, Compressive Behaviour of Sisal Fibre Reinforced Ternary Concrete at Elevated Temperatures, International journal of Advancements in Research \& Technology, Vol. 3, No.8, pp. 123-131, 2014.

3. M.V. Krishna Rao, P. Rathish Kumar, B. Srinivas, Effect of size and shape of specimen on compressive strength of glass fiber reinforced concrete (GFRC), Architecture and Civil Engineering, Vol. 9, No 1, pp. 1-9, 2011.

4. P. Jyotsna Devi, K. Srinivasa Rao, Performance of steel fiber reinforced Concrete at Elevated Temperatures: A Review, The IUP journal of Structural Engineering, Vol. 3, No.8, pp. 53-59, 2013.

5. Farhad Aslani, Bijan Samali, Constitutive relationships for steel fibre reinforced concrete at Elevated temperature, Vol. 50, No.5, pp. 1249-1268, 2014.

6. E. Nikolaidis,R.T. Haftka, Theories of Uncertainty for Risk Assessment when Data is Scarce, International Journal for Advanced Manufacturing Systems, vol.4, No.1, pp. 49-56, 2001.

7. M.Maslak, Selected aspects of failure probability assessment for fire situation, Archives of Civil Engineering, vol. LVII, issue 3, pp. 297-311, 2011.

8. A. Dudzik, U. Radon, The evaluation of algorithms for determination of the reliability index, Archives of Civil Engineering, vol. LXI, issue 3, pp. 133-147, 2015.

9. E. Radziszewska-zielina, B. Szewczyk, Controlling partnering relations in construction operations using fuzzy reasoning, Archives of Civil Engineering, vol. LXI, issue 3, pp. 89-104, 2015

10. J. Konior, Random and fuzzy measure of unpredictable construction works, Archives of Civil Engineering, vol. LXI, issue 3, pp. 75-88, 2015

11. K. Srinivasa Rao, Potha Raju, P.S.N. Raju, Effect of Elevated Temperature on Compressive Strength of HSC Made with OPC and PPC, Indian Concrete Journal, Vol. 80, No. 08, pp. 43-48,2006.

12. Y. Mohammadi, R.Carkon-Azad Singh, S.K.Kaushik, Impact resistance of steel fibrous concrete containing fibers of mixed aspect ratio, Construction and Building Materials, Vol 23, No.1,pp.182-189,2009. www.sciencedirect.com

13. N. Ganesan, T.Sekar, Effect of micro-silica and steel fibres on the strength of high performance concrete composites, Journal of Structural Engineering, Vol. 33, No. 03, pp. 225-229. 2006. 


\section{LIST OF FIGURES AND TABLES}

Fig. 1. Frequency distribution of $\mathrm{R}_{7}{ }^{*}$ of Experimental and simulated data

Rys. 1. Rozkład częstotliwości $\mathrm{R}_{7}{ }^{*}$ danych doświadczalnych i symulowanych

Fig. 2. Cumulative distribution of $\mathrm{R}_{7}{ }^{*}$ for experimental and simulated data

Rys. 2. Skumulowany rozkład $\mathrm{R}_{7}{ }^{*}$ danych doświadczalnych i symulowanych

Fig. 3. Log Normal Probability Paper Plot for $\mathrm{R}_{7}{ }^{*}$

Rys. 3. Zapis normalnego wykresu prawdopodobieństwa dla $\mathrm{R}_{7}{ }^{*}$

Fig. 4. Safety Factor vs Failure probability of fibrous concrete before thermoshock

Rys. 4. Czynnik bezpieczeństwa vs prawdopodobieństwo awarii betonu włóknistego przed szokiem termicznym

Fig. 5. Safety Factor vs Failure Probability of fibrous concrete after thermo shock

Rys. 5. Czynnik bezpieczeństwa vs prawdopodobieństwo awarii betonu włóknistego po szoku termicznym

Fig. 6. Safety Factor vs Failure Probability of fibrous concrete before and after thermoshock

Rys. 6. Czynnik bezpieczeństwa vs prawdopodobieństwo awarii betonu włóknistego przed i po szoku termicznym

Tab. 1. Properties of Ingredients

Tab. 1. Właściwości składników

Tab. 2. The details of fibres used

Tab. 2. Szczegóły użytych włókien

Tab. 3. Mix Details

Tab. 3. Szczegóły mieszanki

Tab. 4. Ratio between Cube and Cylinder Compressive strength of fibrous concrete

Tab. 4. Stosunek między wytrzymałością na ściskanie sześcianu i cylindra betonu włóknistego

Tab. 5. Statistical Properties of Random variables of fibrous concrete cube

Tab. 5. Właściwości statystyczne losowych zmiennych sześcianu betonu włóknistego

Tab. 6. Statistical Properties of Random variables of fibrous concrete cylinder

Tab. 6. Właściwości statystyczne losowych zmiennych cylindra betonu włóknistego

Tab. 7. Probabilistic Values of Ratio between cube and cylinder fibrous concretes

Tab. 7. Probabilistyczne wartości stosunku między sześcianem a cylindrem betonu włóknistego

Tab. 8. Probabilistic, Characteristic and Allowable ratio for evaluating allowable designed Cylinder Compressive Strength

Tab. 8. Probabilistyczny, charakterystyczny i dopuszczalny współczynnik do oceny dopuszczalnej przewidywanej wytrzymałości na ściskanie cylindra

Tab. 9. Comparative Analysis of Probabilistic strength, characteristic strength and designed strength with reported experimental strength

Tab. 9. Analiza porównawcza siły probabilistycznej, siły charakterystycznej i planowanej siły o zgłoszonej sile eksperymentalnej 


\title{
POSTĘPOWANIE W PRZYPADKU NIEPEWNOŚCI W PRZYPISYWANIU SZOKU TERMICZNEGO W WYTRZYMALOŚCI BETONU WŁÓKNISTEGO: PODEJŚCIE PROBABILISTYCZNE
}

\author{
Slowa kluczowe: Beton włóknisty, Rozkład normalny, Prawdopodobieństwo, Kontrola jakości, Niezawodność, \\ Szok termiczny.
}

\section{STRESZCZENIE:}

Większość krajów korzysta z sześciennych próbek, a kilka innych używa próbek cylindrycznych w celu ustalenia wytrzymałości na ściskanie betonu. Na ogół wytrzymałość na ściskanie cylindra jest nieuczciwie ustalana jako 0,8 wytrzymałości sześcianu na ściskanie, ale doświadczenia wykazały, że nie ma unikalnego związku między wytrzymałością sześcianu a wytrzymałością cylindra. Podobna sytuacja występuje również w przypadku betonu włóknistego. Zgodnie z raportem komisji Amerykańskiego Instytutu Betonu ACI 544.2R okazuje się, że nie podjęto próby wykazania probabilistycznego związku między wytrzymałością sześcianu na ściskanie a wytrzymałością cylindra w przypadku żelbetu. Obecnie wytrzymałość materiałów konstrukcyjnych jest wymagana, ponieważ gaszenie pożaru wodą prowadzi do szoku termicznego. Przewidywanie wytrzymałości próbki sześciennej lub cylindrycznej przed i po szoku termicznym jest wymagane w przypadku betonu włóknistego różnych typów.

W niniejszej pracy eksperymentalnej wytrzymałość na ściskanie betonu włóknistego jest traktowana jako zmienna losowa, w której istnieje kilka niepewności, co ma wpływ na łączną zmianę wytrzymałości w wyniku zmian jakości składników betonu, właściwości włókien, ważenia, mieszania, utwardzania i procedur badawczych. Również wiedza na temat zachowań materiałów stale się rozwija, a ich statystyczne deskryptory również się zmieniają wraz z zbieraniem coraz większej ilości danych oraz ich aktualizacją. Niemiej jednak uzbieranie wszystkich danych pola dla różnych składników betonu włóknistego jest zarówno niemożliwe, jak i drogie. Taki stan rzeczy powoduje trudną sytuację w przypadku ustalania zdecydowanego związku między nimi z powodu niepewności związanych z betonem, a także właściwości włókien lub mogą być spowodowane niewystarczającą ilością danych. Techniki symulacyjne są jedynym skutecznym narzędziem do analizowania odpowiedzi losowo napędzanego układu w celu rozwiązania takiej sytuacji, co jest zazwyczaj obliczane przez różne równania. Jest to powodowane zbiorem danych wejściowych, które są kompatybilne z wcześniej opisanym modelem probabilistycznym oraz charakteryzujących ten model przez odpowiedni rozkład, taki jak rozkład normalny lub logarytmiczno-normalny. Później, symulując zestaw losowych liczb, które są kompatybilne z podaną funkcją gęstości mocy układu, udział ilościowy odpowiedzi jest przetwarzany statystycznie w celu oszacowania parametrów lub deskryptorów, takich jak średnia, odchylenia, skośność i kurtoza. W konsekwencji, przeprowadzono analizę probabilistyczną w następujących dwóch fazach ustalania związku $\mathrm{R} *$ między wytrzymałością na ściskanie sześcianu i cylindra różnych betonów włóknistych.

W fazie-I, przeprowadzono analizę niezawodności w celu przeanalizowania doświadczalnego wytrzymałości na ściskanie sześcianu i cylindra różnych betonów włóknistych poprzez wzięcie pod uwagę różnych właściwości materiałowych związanych $\mathrm{z}$ nim $\mathrm{w}$ celu ustalenia odpowiedniej wytrzymałości probabilistycznej wraz z współczynnikiem funkcji zmienności i gęstości prawdopodobieństwa dla swojego typu rozkładu. Obserwując wartość 
współczynnika zmienności (COV), wszystkie wartości COV mieszczą się w dopuszczalnej wartości $15 \%$ i można stwierdzić, że wszystkie wyniki badań spełniają wymagania kontroli jakości.

W fazie II, wykorzystano dane z techniki symulacji Monte-Carlo z fazy I w celu symulacji losowego zachowania związku między wytrzymałością na ściskanie sześcianu a wytrzymałością cylindra biorąc pod uwagę wytrzymałość jako losową zmienną zależną od złożonych właściwości materiałowych różnych typów betonu włóknistego, takich jak beton włóknisty z włóknami ze stali, szkła odpornego na działanie alkaliów i poliestru przed i po szoku termicznym $R_{i=103}^{*} \cdot R_{i=4 t o 6}^{*}$ Niemniej jednak symulowane modele probabilistyczne, charakterystyczne, zoptymalizowany czynnik bezpieczeństwa oparty na niezawodności i dopuszczalna wytrzymałość na ściskanie cylindra również zostały opracowane.

W tym znaczeniu, niektóre główne wnioski zostały wyciągnięte z tych badań.

I. Co niezwykłe, przed i po szoku termicznym, wytrzymałość na ściskanie sześcianu i cylindra nie zmieniała się i okazało się, że rosła niezmiennie wraz ze wzrostem wielkości włókien.

II. Opracowane modele probabilistyczne dla związku między wytrzymałością na ściskanie sześcianu i cylindra różnych rodzajów betonu włóknistego, takich jak beton włóknisty z włóknami ze stali, szkła odpornego na alkalia i poliestru, przed i po szoku termicznym, będą przydatne do uzyskania wytrzymałości na ściskanie cylindra $\mathrm{z}$ betonu włóknistego.

III. Niemniej jednak charakterystyczne modele związku są również opracowane do odróżniania charakterystycznej wytrzymałości na ściskanie cylindra od wytrzymałości sześcianu z betonu włóknistego. Będą one idealne do projektowania konstrukcji żelbetowych. Opracowano również zoptymalizowany czynnik bezpieczeństwa i dopuszczalną zaprojektowaną wytrzymałość na ściskanie cylindra, i takie modele wykazują solidną wydajność w przypadku realistycznych obiektów inżynieryjnych. 
